\title{
Polysèmes
}

Revue d'études intertextuelles et intermédiales

"Governments and fashions come and go, but Jane Eyre is for all time": Jasper Fforde's Confrontation with the Victorian Canon and Quest for Authorship

"Les gouvernements et les modes peuvent bien changer, mais Jane Eyre, c'est intemporel »: confrontation auctoriale avec le canon victorien et quête

d'autorité

\section{Amelha Timoner}

\section{(2) OpenEdition}

\section{Journals}

Electronic version

URL: http://journals.openedition.org/polysemes/6602

DOI: $10.4000 /$ polysemes.6602

ISSN: 2496-4212

Publisher

SAIT

Electronic reference

Amelha Timoner, " "Governments and fashions come and go, but Jane Eyre is for all time": Jasper Fforde's Confrontation with the Victorian Canon and Quest for Authorship », Polysèmes [Online], 23 | 2020, Online since 30 June 2020, connection on 02 July 2020. URL : http://journals.openedition.org/ polysemes/6602 ; DOI : https://doi.org/10.4000/polysemes.6602

This text was automatically generated on 2 July 2020.

Polysèmes 


\section{"Governments and fashions come and go, but Jane Eyre is for all time": Jasper Fforde's Confrontation with the Victorian Canon and Quest for Authorship}

"Les gouvernements et les modes peuvent bien changer, mais Jane Eyre, c'est intemporel »: confrontation auctoriale avec le canon victorien et quête d'autorité

Amelha Timoner

1 Jasper Fforde's Thursday Next novels partake of the current authorial trend of seizing canonical works of literature and claiming them as their own. However, the author does this not through the means of realist fiction, but rather through fantasy and alternate history. ${ }^{1}$ Thursday's world is similar enough to our own that the reader can find their footing without too much difficulty, but it differs in various aspects. As far as history goes, the Crimean War is not over in this alternate 1985, Wales has become a People's Republic and England does not have a Prime Minister, but a President for Life. Time travel is possible, and technology is so advanced that some extinct species like dodos and mammoths have been brought back to life. And yet, even if this world seems to be turned towards the future, it is in fact haunted by the past. The entire population is indeed obsessed with canonical works, but this fascination does not stop at musing about Shakespeare's true identity. Characters physically engage with revered texts, whether by attending participatory performances of Richard III or by going inside fiction to rescue an abducted Jane Eyre. The author is therefore also involved in this literary enterprise: Fforde establishes a co-dependent relationship between the first volume of his cycle, The Eyre Affair (2001) and Jane Eyre. In so doing, he questions the 
closure of Brontë's novel. Whether he manages to find his authorial voice or not remains to be seen, given the fame of the literary work he seizes.

The purpose of this article is twofold: first, it will examine the parodic relationship between Jane Eyre and The Eyre Affair, and the consequences it bears on Fforde's authorship. It will then investigate the shift in authorial stance, revealed by the role given to the Victorian canon in the cyclic and metafictional expansion of the 'Thursday Next' novels. I will then particularly focus on the second and third volumes, Lost in a Good Book and The Well of Lost Plots respectively.

Before going any further in the analysis of the novel, it is worth mentioning that, in Thursday's alternate world, Jane Eyre does not end the way we know. Far from returning to Rochester after Thornfield has burnt to the ground-and after Bertha has conveniently died-Jane decides to go to India with her long-lost cousin, St John Rivers, as her assistant, to the dismay of the readers. The lack of satisfying ending is verbalised by an American tourist visiting the Brontë museum as early as chapter 6 of The Eyre Affair: "Yeah, well, she agrees to go with this drippy St John Rivers guy but not to marry him, they depart for India and that's the end of the book? Hello? What about a happy ending? What happens to Rochester and his nutty wife?" (65).

These unanswered questions are then taken up again later in the plot by Thursday and her colleague Bowden, who has never read the story:

"[T]he ending does sound a bit of an anticlimax. [...] If I had been Charlotte I would have made certain that Rochester and Jane were reunited-married, if possible."

"Don't ask me," I said, "I didn't write it." I paused. "You're right, of course," I murmured. "It is a crap ending. Why, when all was going so well, does the ending just cop out on the reader? Even the Jane Eyre purists agree that it would have been far better for them to have tied the knot". (270)

5 The Eyre Affair offers a counterfactual continuation of a fictional counterpart of Jane Eyre, which I will henceforth refer to as JE' to differentiate it from Brontë's actual novel. For us, JE' is a possible world exploring the consequences of "What if Jane had decided to go to India rather than go back to Rochester?". But for Thursday and the other characters inhabiting her world, JE' is what Marie-Laure Ryan calls the textual actual world (72), while "What if Jane had decided to go back to Rochester rather than go to India?" remains wishful thinking on the part of the readers.

6 The Eyre Affair and Jane Eyre consequently have a transfictional relationship, as defined by Richard Saint-Gelais, i.e. "the phenomenon by which at least two texts, from the same author or not, share the same plot, be it by reusing characters, extending a previous plot or sharing a fictional universe" (Saint-Gelais 2011, 7).

7 The two novels partly share the same fictional place, Thornfield Hall. They bear similarities in terms of characters and plot, mostly through the means of parodythough $\mathrm{Fforde}$ sometimes resorts to pastiche. Parody and pastiche signal a hypertextual relationship with a hypotext, but one of a different kind, especially in a neo-Victorian context. Christian Gutleben argues that:

[A]ll the definitions of parody stress the comic or playful discrepancy between the target text and the parody; this discrepancy may entail either criticism or sympathy [see Hutcheon 30-33], but in this very possibility of criticism lies a fundamental subversive power. On the other hand, pastiche 'does not usually have the comically incongruous structure or comic effect of the parody. [It] is a more neutral form of compilation'. (Gutleben 2001, 8) 
Even if humour is widely used in parodies, it does not mean that the aim of the parodist is necessarily to ridicule the hypotext, though it is sometimes the case (Hutcheon 32). Rather, it can be a "respectful homage" (Hutcheon 33) paid to a canonical work through a "repetition with difference" (Hutcheon 32) rendered possible by temporal distance:

[I]f the perspective is contemporary, that is if the narrative situation and voice are situated in the twentieth century, the Victorian allusions, references and echos will necessarily be parodic since there cannot be an allusion of faithful imitation. (Gutleben 2001, 8)

9 Repetition with difference is clearly visible in the title of Fforde's first novel, The Eyre Affair. It seems to be subjected to its Victorian predecessor, the only difference being in the 'Affair'. It sounds-partially through the assonance in the title-as if Fforde's novel were a mere rewriting trying to spice things up thanks to this sensationalist noun. It sheds new light on this beloved classic by revealing the skeletons hidden in the attic, not just Bertha. Of course, in the end, Fforde's aim is to leave his mark on Jane Eyre, but the path he takes to do so is richer than adding scenes to satisfy an avid reader (who has likely read all fanfiction available about Brontë's characters).

Parody manifests itself in the form of parallels between Jane Eyre and The Eyre Affair, both in character descriptions and in the diegesis itself. Several characters in The Eyre Affair bear striking resemblances to those from Jane Eyre. In the first chapters of Fforde's novel, the reader finds a physical description of its protagonist, Thursday: "A woman with somewhat ordinary features stared back at me. Her hair has a plain mousey colour and of medium length, tied up rather hastily in a ponytail at the back. She had no cheekbones so to speak of [...]" (20). Thursday's simple, or even plain, looks are close to Jane Eyre's when she harshly describes herself or is described by others: "[the] portrait of a governess, disconnected, poor and plain" (187), "poor and obscure, and small and plain [...]" (294). Besides, when Thursday, aged nine, finds herself transported into the Victorian novel by chance, she sees Jane Eyre, sitting on a stile and about to meet Rochester for the first time. Struck with her appearance, she is immediately drawn to her and considers her a role model (Hateley 127):

I stared at her intently with a mixture of feelings. I had realised not long ago that I myself was no beauty, and even at the age of nine had seen how the more attractive children gained favour more easily. But here in that young woman I could see how those principles could be inverted. I felt myself stand more upright and clench my jaw in subconscious mimicry of her pose. (Fforde 2001, 66)

11 The Eyre Affair and Jane Eyre seem to be linked early in the diegesis, both because of Thursday's incursion in the Victorian novel and because of the little girl's desire to look like Jane Eyre. That being said, physical traits are not the only resemblances between the two protagonists. Both have a strong moral compass: Jane refuses to elope with Rochester because he is already married, while Thursday turns down Hades's offer to work with him, despite his magical powers of persuasion. Both decline moving to another continent with someone they cannot love. Finally, their likeness reaches its tipping point when, once Thursday has managed to read herself into Jane Eyre, she reacts in the same way as Jane to a question asked by Rochester:

"Do you think me handsome, Miss Next?" he asked quite suddenly.

"No," I answered truthfully.

"Bah!" exclaimed Rochester. "Pixies both! Begone with you; we will talk later!" (233) 
two main male characters from The Eyre Affair find counterparts in Jane Eyre, one as the love interest, the other as the unrequited lover. Landen Parke-Laine, Thursday's expartner, embodies a version of Rochester. Although he did not lose a hand or his sight when his mansion was destroyed, he did lose a leg during the Crimean War. Just as Rochester betrayed Jane's trust with his former marriage to Bertha, Landen betrayed Thursday when he accused her brother of leading his soldiers to death during the war. The resemblance to Rochester goes further since, when Thursday meets him again after ten years' separation, he is about to marry Daisy Mutlar, who is just as mercenary and agreeable as Blanche Ingram. Their resemblance is in fact literally mentioned by Rochester and Thursday, emphasizing the link between the two women (333).

inally, Bowden Cable, Thursday's younger colleague, with his lack of sense of humour and his bred-to-the-bone moral integrity, is one of the avatars of St John Rivers-the second being Hades, as Erica Hateley points out (1026)-when he asks Thursday if she would go with him to the United States, where he has been offered a job:

"Have you ever-um-been to Ohio?" he asked in an innocent tone of voice.

"No." [...]

"And they said I could bring someone with me."

"Who do you have in mind?"

"You" (Fforde 2001, 226-227).

The likeness between The Eyre Affair and Jane Eyre therefore lies not only in their similar characters but in the plot, as Bowden's proposal shows. True to its parodic form though, its "repetition with difference" (Hutcheon 31), the proposal remains an unexplored diegetic branch and Thursday's dealings with a villain who loves literature as much as she does-though not for the same reasons-are brought to the fore. And so, The Eyre Affair and Jane Eyre do not merely follow loose parallel plotlines which never meet. Quite the reverse: they indeed intertwine more and more as the plot progresses and their mutual influence reveals the inner authorial struggle that Fforde experiences, as he tries to shake off the weight of Charlotte Brontë's authority.

Thursday intervenes several times in the Victorian novel. At first, she is unaware that she disrupts it, but later on she consciously alters the plot. She first interferes as a little girl, by making Rochester slip on the patch of ice and fall off his horse when he meets Jane for the first time. Apparently, before her appearance and the surprise she caused the protagonist, the two characters only "spoke briefly" (Fforde 2001, 190). As Rochester tells her later when they meet again: "Your intervention improved the narrative. [...] When the horse slipped to avoid you it made the meeting more dramatic, wouldn't you agree?" (190). This comment illustrates the power invested in Thursday, even as a child. She is presented as the one who will set the narrative right and, through her, Fforde's agency as an author is asserted.

However, her greatest interference does not just dramatise a scene, but also completely changes the end of Jane Eyre. Unsatisfied with its end, but also sensitive to Rochester and Jane's distress, Thursday deliberately intervenes in the canonical plot so that the protagonists may marry:

I made it back to Ferndean and Rochester just before Jane did. I met Rochester in the dining room and told him the news; how I had found her at the Rivers' house, gone to her window and barked: "Jane, Jane, Jane!" in a hoarse whisper the way that Rochester did. It wasn't a good impersonation but it did the trick. I saw Jane start to fluster and pack almost immediately. (346) 
This turn of events comes as a surprise, because of its light tone. The supernatural element that the reader knows, i.e. the fact that Rochester's beloved can hear his crying out to her from across England, is neutralised in this fictional counterpart and transformed into a comic scene. Here, Thursday badly imitates Rochester's voice and Jane, supposedly a rational creature, falls for it. The climax takes on a parodic dimension as the noble subject is transformed and treated comically, and there follows a reversal of authority: the timeless love story is made possible thanks to a comic process, which could almost have come from the commedia dell'arte, with Thursday as a Harlequin, defending the lovers' interests.

Acting as she does, Thursday not only "authorises" Rochester and Jane's wedding, but she also authors the novel (345) and replaces Brontë, who is thoroughly absent in The Eyre Affair as Erica Hateley very convincingly argues:

This erasure of authorial presence-beyond the conflation of Brontë with Thursday - could be read as a fetishization of the text in and of itself [...]. It might be suggested that Fforde's own authorial presence displaces Brontë, effectively containing her as a cultural presence. (Hateley 1033)

19 By erasing Brontë and her protagonist-Jane Eyre being a first-person narrative, any interaction with Jane would result in diegetic modifications-Fforde manages to overcome his reader status and anxiety of influence (Bloom 57) to gain authorship. He gives the impression that Jane Eyre has passed through his hands to be augmented (Arendt 121-122) and that, thanks to his input, the novel now resembles the version that readers and academics know.

However, Fforde's seizure of power is short-lived, for if his characters influence Brontë's plot, in the end his rewriting of the canonical novel is a mere illusion, as Jane Eyre remains intact. Besides, if Thursday interferes several times to help Jane and Rochester, it is the intervention of a character from Jane Eyre that saves the day and allows her to be reunited with her ex-partner, Landen. Indeed, his wedding ceremony with Daisy Mutlar is interrupted by Mr Briggs, the same attorney who prevented Jane and Rochester from marrying. Admittedly, contrary to Jane Eyre, Landen/Rochester is not the one accused of bigamy, Daisy/Blanche is, and the result is comic rather than dramatic.

21 While the rest of The Eyre Affair is a parody of Jane Eyre, both paying tribute to this great novel and aiming to undermine Brontë's authorship thanks to Ffordian interventions, the final wedding scene questions the parodic relationship. Far from a repetition with difference, the scene is a straightforward repetition of Rochester and Jane's disastrous attempt to be wed, especially given that it follows the same chronology and most of the text is lifted, unacknowledged, ${ }^{2}$ directly from the Victorian novel:

"I require and charge you both," the clergyman was saying, "that if either of you know any impediment why ye may not be lawfully joined together in matrimony, ye do now confess it."

[...]The clergyman turned to Landen and opened his mouth to speak, but as he did so there came a loud, clear voice from the back of the church:

"The marriage cannot go on: I declare the existence of an impediment!"

$[\ldots]$

"Proceed!" [Daisy's father] said, his face like thunder.

The clergyman looked at the speaker, then at Daisy and Landen, and finally at Mr Mutlar.

"I cannot proceed without some investigation into what has been asserted and evidence of its truth or falsehood,' he said with a pained expression; nothing like 
this had ever happened to him before. [...] 'What is the nature of this impediment?

Perhaps it may be got over-explained away?"

"Hardly," was the answer. "I have called it insuperable and I speak advisedly. It

consists simply of a previous marriage". (Fforde 2001, 352-353)

Jane Eyre or The Eyre Affair? When reading this scene, doubt remains as the clergyman and Mr Mutlar respectively recite what Mr Wood and Rochester say in Jane Eyre, while Briggs, having been imported from Brontë's novel, only needs to repeat the lines he usually delivers (333-334). Instead of spreading his wings and leaving the canonical plot behind, Fforde goes back to it, going as far as parroting the original text and letting characters from Jane Eyre supply the romantic conclusion in his novel. And thus, Thursday's fate coincides with Jane's, as both marry, embodying the classical comedic resolution and return to a patriarchal order (Hateley 1028).

In its attempt to pay respectful homage to Brontë, The Eyre Affair eventually turns into a conservative parody. Feminine voices, especially Jane's, are silenced, while male ones grow more and more powerful. Thursday submits to Rochester's advice about forgiving her ex-partner as if she were much younger-though the two characters are approximately the same age (Hateley 1033-1034) and Rochester is no model of transparency-even if it means embracing romantic attachment over sibling love, and effectively putting aside Landen's betrayal:

"You have a man you love?" asked Rochester suddenly.

"Yes; but there is much bad air between us. He accused my brother of a crime that I thought unfair to lay upon the shoulders of a dead man; my brother never had a chance to defend himself and the evidence was not strong. I find it hard to forgive". "What is there to forgive?" demanded Rochester. "Ignore forgive and concentrate on living. Life for you is short; far too short to allow small jealousies to infringe on the happiness which can be yours only for the briefest of times".

"Alas!" I countered. "He is engaged to be married!"

"And what of that?" scoffed Rochester.

(Fforde 2001, 332-333).

4 Jane's necessary absence, resulting first from her abduction, and then from her reinstatement in the first-person narrative, turns her into a cardboard cut-out character. She is flat and forgettable, while Rochester is given ample time to justify his life choices to Thursday and the reader, and to act heroically on multiple occasions (Fforde 2001, 62; 335-342). He is written as a broody, handsome-while-not-being-so, and passionate character, as he is remembered in the collective imagination and how he has been portrayed in recent screen adaptations (Susanna White, Jane Eyre, 2007; Cary Fukunaga, Jane Eyre, 2012). On the other hand, positive female characters like Mrs Fairfax and Grace Poole end up testifying against Thursday when she is tried for changing the end of the JE' (Fforde 2002, 153). Bertha Rochester is constantly referred to as the "madwoman" (Fforde 2001, 332) ${ }^{3}$ or "nutty wife" (65), "cackling" (339), her humanity seemingly long gone. In its dialogue with Jane Eyre, Fforde seems to forget that other prominent neo-Victorian works have shed new light on the canonical novel, like Jean Rhys's Wide Sargasso Sea, and his disregarding them defeats one of the purposes of neo-Victorian literature, i.e. "[the] desire to re-write the historical narrative of that period by representing marginalised voices, new histories of sexuality, post-colonial viewpoints and other generally 'different' versions of the Victorian" (Llewellyn 165).

In the same way, Fforde could have chosen a different path for his characters-Jane could have gone to India as an independent woman and not back to Thornfield-which 
would have made JE' a counterfactual version ${ }^{4}$ of Jane Eyre with Jane's decision to accompany her cousin as the starting point. However, by staging an identical denouement, JE'-and by extension The Eyre Affair, since both plots are metaleptically intertwined-are turned into an interpolation, to use Saint-Gelais's word, ${ }^{5}$ of Jane Eyre: Fforde fills narrative gaps in the canonical novel, but his leverage is limited by Brontë's diegetic decisions and, in the end, his choice to comply with them.

Even if The Eyre Affair, by merely existing, questions the closure of Brontë's novel, ${ }^{6}$ it remains Jane Eyre's satellite inasmuch as the author engages with the canonical novel through the means of parody, which is always paradoxically authorised by the text it seeks to subvert. ${ }^{7}$ However, Fforde appears to welcome this submission, since he rejects potential authorship by transforming his counterfactual version-which would have given him more freedom to expand the textual universe-into an interpolation. This effectively reduces his autonomy, given that the beginning and the end of the plot are decided by his forebear.

Subsequently, Fforde engages differently with the canon in the volumes published after The Eyre Affair. Rather than developing a strong relationship with a particular text, he creates an intensely metafictional secondary world for his cycle. Its centripetal force attracts canonical characters, revealing the authorial desire to become the centre of gravity, and not just a satellite orbiting around a Victorian planet.

Series and cycles maintain a different relationship with their volumes. As Anne Besson argues, repetition is the core of series while in cycles, time passes, which affects characters and transforms the world(s) they live in (Besson 22-23). And so, the Thursday Next novels are a chronological cycle (23)-even if the plots resemble one another, with Thursday often saving the world from impending doom, and even if they tend to be more and more ludicrous. From preventing the world from turning into pudding, to helping Hamlet fight a rebellion in his play, the reader is indeed left wondering what the author will invent next. Through a substantial construction of the secondary world, Fforde gains an authorship of his own, away from unstable relationships with Victorian giants.

The chronology in The Eyre Affair is not consistent, leading the reader to think that the novel was probably meant to be a stand-alone work. Indeed, determining how much time elapses between different peripeteias proves difficult because of frequent ellipses. This is particularly challenging due to the presence of time-jumps, both backwards and forwards, in the first ten chapters. After Thursday is hurt during her first confrontation with Hades in chapters 3 and 4, she spends two weeks in the hospital following a severe injury. There, she relates her encounter with Hades to SpecOps-1, the police of SpecOps before receiving a visit from... herself, in a shiny car, warning herself about Hades's fake death. ${ }^{8}$

30 This scene is echoed later in the novel when Thursday, now a member of Swindon's LiteraTecs, is driving said car and ends up in the hospital room where she finds herself sitting on the bed, and instructs her other self to go to Swindon. ${ }^{9}$ By doing so, she closes the time loop while also creating a time paradox. For, if she had not told herself to go to Swindon, she would not have been able to take the LiteraTec job there, then find herself in a position to accidentally go back in time, visit herself in the hospital to give the warning, and so on.

31 The chronology of the diegesis becomes more stable as the cycle progresses, and this stability reaches an extreme in the last volume, The Woman Who Died a Lot. Here, all 
chapters begin with a weekday, and all the peripeteias occur in about a week. ${ }^{10}$ Thursday also ages throughout the cycle, beginning in her mid-thirties in The Eyre Affair and ending The Woman Who Died a Lot in her fifties (for now), as Fforde has not yet provided closure to the cycle.

Contrary to series which favour limited textual universe and repetitive plotlines, cycles offer an expandable world that the protagonist explores in the course of their adventures (Besson 22-23). The second and third volumes, Lost in a Good Book and The Well of Lost Plots respectively, present a broader secondary world which was not hinted at in The Eyre Affair, but proves to be a logical expansion. There are two reasons for this: on the one hand, its increasing metafictionality drives the world towards autonomy and, on the other hand, numerous Victorian characters play an essential part in its development.

Literature and the creative process are an integral part of the BookWorld, whose heart is The Great Library, a fictional place whose upper part contains all the novels that have been and will ever be written in the English language (Fforde 2002, 164). Characters desiring to read themselves into a particular novel need to go through it, and all the agents of Jurisfiction, i.e. the police inside fiction, report to The Council of Genres, on its top floor. Located in the lower part of the building is the Well of Lost Plots, where stories that are being written or that have been discarded are stored. The place swarms with characters of all shapes and sizes, but also with shops selling backstories such as "Misguided feelings of guilt over the death of a loved one/partner ten years previously" (Fforde 2003, 53) or plot devices such as "Do we cut the red wire or the blue wire?" (56) or "Suddenly, a Shot Rang Out!" (60).

Fforde's world-building thus becomes more complex in the volumes following The Eyre Affair, not only because he creates and expands two more worlds. Even if both exist within the BookWorld, they are distinct, the upper part consisting of an orderly place while the lower part is a chaotic one (48). The complexity also increases because the metafictional aspect is expanded throughout the cycle, and becomes of utmost importance.

The Well embodies the place where the barrier between fiction and reality is at its thinnest, since it reveals the machinery exerted by creative writing. In particular, it sheds a light on the relationship between authors and their works-in-progress:

Tradesmen, artisans, technicians and Generics all walked about the broad corridors appearing and vanishing as they moved from book to book, building, changing and deleting to the author's wishes. Crates and packing cases lay scattered about the corridor and people ate, slept and conducted their business in shops and small houses built in the manner of an untidy shanty town. Advertising hoardings and posters were everywhere, promoting some form of goods or services unique to the business of writing. (48-49)

It would seem that the authorial function, as defined by Hannah Arendt, is divided into two parts: on the one hand, the "auctor", i.e. the true creator who conceptualises the fictional world and, on the other hand, the 'artifex', that is to say the artisan who actually builds it (Arendt 122). In a way, it is suggested that the Well submits to the authors' creative desires. At the same time, by transforming the abstract creative process into a physical one which requires an army of workers, the creator's authority is undermined as it seems tyranical (97). In the same fashion, the romantic idea of the lonely writer inspired by a muse is deconstructed. 
Gelais 1999, 312) and rules, whose aim is completeness. As Besson argues:

[...] progressively, through the succession of volumes which explore it in different ways, the fictional world appears more and more substantial, and can even be considered a complete world, simultaneous to our own. (Besson 126-127, my translation)

Victorian characters from their habitat to people this metafictional world in Lost in a Good Book and The Well of Lost Plots. In doing so, he reverses the hierarchical relationship with his forebears as he becomes (or at least aims to become) the centre of gravity, attracting Victorian meteors which cross ontological boundaries and play a significant part in the construction of his metafictional world. Canonical characters either actively contribute to the main plot or serve expositional purposes for both protagonist and reader, since both discover a new world. Miss Havisham becomes Thursday's supervisor for her Jurisfiction training, and takes her to various places in the BookWorld and on several missions which clarify the rules she has to follow. ${ }^{11}$ The Cheshire Cat-renamed The Unitary Authority of Warrington Cat- introduces Thursday to the logistics of the Great Library ${ }^{12}$ and occasionally helps her find information to solve a case (Fforde 2004, 264-267).

41 Commander Bradshaw is an essential character both for the plot and the construction of the Ffordian universe. Excerpts from Bradshaw's Guide to the BookWorld in epigraphs offer useful information to the reader about this new world: details about important events like the Annual BookWorld Awards (Fforde 2003, 329), devices used by Jurisfiction agents, etc. By relegating this fictional artefact to the peritext, ${ }^{13} \mathrm{Fforde}$ avoids what Richard Saint-Gelais calls 'shameful didacticism' (Saint-Gelais 1999, 158) and does not weigh down his text: a reader already familiar with his novels can easily skip the epigraph opening the chapter.

42 Besides, Bradshaw is not a canonical character but the personification of a travel guide which was developed during the Victorian era and which is still famous to this day. Through him, Fforde not only reworks the literary canon, but also addresses the concerns of the era, mainly the developement of rail travel. He uses this to his own advantage, since speculative fiction thrives in the exploration of foreign lands.

Numerous other characters from the canon are anecdotally summoned to the Ffordian universe so that the reader can catch a glimpse of who they truly are when they are not being read. For example, Thursday finds Marianne Dashwood smoking at the back of Norland Park, has to prevent Lucy Deane from killing Maggie Tulliver when she is out boating with Stephen Guest, and helps to run a disastrous counselling session in Wuthering Heights where, unsurprisingly, all the characters hate one another (Fforde 2003, 123-134).

All these characters, and many more, have a personality similar to their original one, giving the impression that they are not merely counterparts (Saint-Gelais 2011, 43-44) 
but rather the same character: the Red Queen has a temper, the Cheshire Cat is fond of cryptic sentences, Miss Havisham is brusque in her manners and Hamlet is unable to make a decision, even when choosing a hot beverage.

In the first volume, characters from JE' insist on the power of text-and, consequently, of their author-over them. They admit that even if they enjoy some freedom when narration is not upon them, their personality is not different from the part they play in the novel ${ }^{14}$ and they cannot act out of character or escape their fate, because they are "written that way". ${ }^{15}$ Mrs Fairfax puts it very aptly when Thursday is at a loss as to why Rochester would go to the Eshtons, after Jane has been safey returned to the plot, but Hades is still at large:

"With all that is going on here, do you think it is wise?"

Mrs Fairfax looked at me as though I were an infant.

"You don't understand, do you? After the fire Mr Rochester goes away for a week.

That's how it happens." (Fforde 2001, 323)

On the contrary, borrowed Victorian characters appearing later in the cycle seem to be freer from the constraints of their original narrative, mostly because they interact with Thursday in the Ffordian universe and not in their actual world, i.e. the book they come from. Most of them are not subjected to their fate, but rather seem to embrace a different life outside the closed textual world they inhabit. Miss Havisham regularly leaves Great Expectations to pursue various missions, be they Jurisfiction matters like killing grammasites in the Well, or for her own pleasure, like racing against $\mathrm{Mr}$ Toad in vintage cars.

Fforde therefore acts as a phagocycle, as Saint-Gelais rightly points out (SaintGelais 2008, 271): the Great Library indeed enables him to summon any character in the public domain. He rejects the closure of Victorian texts and offers a new world infused with futuristic technology the borrowed characters could only imagine, since they come from nineteenth-century mimetic fiction. He also gives them a chance to live a second and possibly different life if they so choose, outside of their original source. ${ }^{16}$ All these borrowed characters are therefore empowered to leave the constraints of their original finite text and evolve through the means of the Great Library, which contains an infinite variety of literary worlds within its walls-books of various genres are constantly published. Since the novels are incorporated in the Ffordian universe, canonical characters are allowed to thrive away from the Victorian authorial weight. However, in this liberating process, their original complexity suffers, as the cycle is more plot- than character-driven. Like Jane Eyre in The Eyre Affair, most are archetypes far from the great Victorian protagonists they normally are: Heathcliff is reduced to a selfish man whose career in Hollywood is more important than the novel he is from, and Miss Havisham is turned into a grumpy but caring woman addicted to sports cars.

When Fforde rewrites or borrows from Victorian novels, he does not only seek to reclaim their fame or seduction (Gutleben 1998, 169). His aim is also to establish a relationship with his readership thanks to the canon, especially because it is part of collective memory. Many people have studied Brontë, Dickens or Eliot, or are at least familiar with the plots of their most well-known novels. He therefore creates an intellectual complicity between himself and the reader, who delights in searching for the references disseminated throughout the novels. Most of them are now considered highbrow, ${ }^{17}$ as previously demonstrated, but some are part of folklore, in the form of nursery rhyme characters: for instance, Humpty Dumpty is the spokesperson for all 
nursery rhyme characters desiring to settle somewhere and not just live in oral tradition (Fforde 2003, 100-101). Additionally, there are references to contemporary popular culture: Daleks (from the famous TV series Dr Who) live in a part of the Well called the Bestiary, along with unicorns, dragons and various creatures (75) while the head of Jurisfiction utters a sentence directly taken from a TV show from the 1980s at the end of each meeting (TV Trope, Series/Hill Street Blues).

The proliferation of references ensures that the reader finds at least some of them, depending on their age and nationality. Indeed, as most references are British, international readers can find it difficult to understand them, especially if puns are lost in translation. ${ }^{18}$ An authoritative relationship seems to be created between the one who commands-Fforde as the omnipotent author-and the one who obeys (Arendt 93)-the reader, trying to find their way through the layers of references. But in order to prevent the neutralisation of allusions, Fforde's website steps in. The first four volumes have therefore been meticulously combed through by attentive readers who have created a "Non-Brit Guide to the Thursday Next series" (Brierley), "The exhaustive guide to The Well of Lost Plots" (Tymens, et al, 2004) and "The exhaustive guide to Something Rotten or Something Rotten- decomposed" (Tymens, et al, 2005). And so, the tables have turned: the author who was once authorised when he parodied Jane Eyre now authorises readers to contribute to his literary creation, the guides featuring on his website.

Fforde has come a long way in his writing process, from shadowing a Victorian text to creating and expanding a multiplicity of worlds combining highbrow literature, popular culture and a generous helping of metafiction. He gradually forges his authorship as he writes the Thursday Next cycle, the latter gaining stability through a better chronological organisation and in-depth world-building. After transcontextualising (Hutcheon 32) a canonical novel, he rejects potential authorship and chooses to remain in Brontë's shadow. Fforde then seizes power by creating a powerful metafictional world whose centripetal force attracts Victorian texts and characters which are turned into material to build it. However, by revealing the inner workings of creative writing, his world questions and debunks his authorship. Likewise, he authorises readers to involve themselves in the process on his website. Therefore, it does not come as a surprise that the literary creation partially slips from his hands as readers eagerly appropriate it and expand it in fanfictions on the internet. In so doing, they manage to go where the author never could, by integrating copyrighted characters such as Harry Potter (bronzedragon). As a result, this illustrates the powers readers have, as Fforde often points out in his novels:

After all, reading is arguably a far more creative and imaginative process than writing; when the reader creates emotion in their head, or the colours of the sky during the setting sun, or the smell of a warm summer's breeze on their face, they should reserve as much praise for themselves as they do for the writer-perhaps more. (Fforde 2003, 50) 


\section{BIBLIOGRAPHY}

Arendt, Hannah. Between Past and Future: Six Exercises in Political Thought. New York: Viking Press, 1961.

Besson, Anne. D'Asimov à Tolkien : cycles et séries dans la littérature de genre. Paris : CNRS Éditions, 2004.

Bloom, Harold. The Anxiety of Influence: A Theory of Poetry. 2nd ed. New York/Oxford: Oxford UP, 1997.

Brierley, Jon. “Jon Brierley's British Reference Notes: A Non-Brit's Guide to the Thursday Next Series", last modified 4 November 2002, http://www.jasperfforde.com/reader/readerjon2.html, last accessed 17 March 2020.

Brierley, Jon. “Jon Brierley's British Reference Notes: A Non-Brit's Guide to the Thursday Next series". Last modified 28 November 2002, http://www.jasperfforde.com/reader/readerjon5.html, last accessed 17 March 2020.

Brontë, Charlotte. Jane Eyre (1847). London: Penguin Classics, 2006.

Brontë, Emily. Wuthering Heights (1847). London: Penguin Classics, 2003.

bronzedragon. "Harry Potter and the Visit from Jurisfiction". Archives of Our Own, June 2012. https://archiveofourown.org/works/434894, last accessed 17 March 2020.

Carroll, Lewis. Alice's Adventures in Wonderland (1865). London: Penguin Classics, 2012.

Fforde, Jasper. The Eyre Affair. London: Hodder and Stoughton, 2001.

Fforde, Jasper. Lost in a Good Book. London: New English Library, 2002.

Fforde, Jasper. The Well of Lost Plots. London: Hodder and Stoughton, 2003.

Fforde, Jasper. Something Rotten. London: Hodder and Stoughton, 2004.

Fforde, Jasper. The Woman who Died a Lot. London: Hodder \& Stoughton, 2012.

Fukunaga, Cary. Jane Eyre. DVD. London: Universal Studios, 2012.

Genette, Gérard. Palimpsests: Literature in the Second Degree. Trans. Channa Newman and Claude Doubinsky. Lincoln, NE/London: U of Nebraska P, 1997.

Genette, Gérard. Paratexts: Thresholds of Interpretation. Trans. Jane E. Lewin. Cambrige:

Cambridge UP, 2001.

Gutleben, Christian. Nostalgic Postmodernism: The Victorian Tradition and the Contemporary British Novel. Amsterdam/New York: Rodopi, 2001.

Gutleben, Christian. "La tradition victorienne à l'heure du postmodernisme : John Fowles, David Lodge, A.S. Byatt”. Études Anglaises 51.2 (April 1998): 167-179. https://search.proquest.com/ docview/1294054658?accountid=13042, last accessed 17 March 2020.

Hateley, Erica. “The End of The Eyre Affair: Jane Eyre, Parody, and Popular Culture”. The Journal of Popular Culture 38.6 (n.d.): 1022-1036. https://doi.org/10.1111/j.1540-5931.2005.00174.x, last accessed 17 March 2020.

Hutcheon, Linda. A Theory of Parody: The Teachings of Twentieth-Century Art Forms (1985). Urbana: U of Illinois $\mathrm{P}, 2000$. 
Letissier, Georges. “Neo-Characterization in the Neo-Victorian Novel”. E-Rea 13:1 (2015). https:// doi.org/10.4000/erea.4834, last accessed 17 March 2020.

Llewellyn, Mark. “What is Neo-Victorian Studies?". Neo-Victorian Studies 1.1 (Autumn 2008): 164-185. http://neovictorianstudies.com/past_issues/Autumn2008/NVS\%201-1\%20MLlewellyn.pdf, last accessed 17 March 2020.

Rhys, Jean. Wide Sargasso Sea (1966). London: Penguin Classics, 2000.

Rose, Margaret A. Parody: Ancient, Modern, and Post-modern. Cambridge: Cambridge UP, 1993.

Ryan, Marie-Laure. Narrative as Virtual Reality 2: Revisiting Immersion and Interactivity in Literature and Electronic Media. Second ed. Baltimore: John Hopkins UP, 2015.

Saint-Gelais, Richard. L'Empire du pseudo : modernités de la science-fiction. Québec : Nota bene, “Littérature(s)", 1999.

Saint-Gelais, Richard. "Une détective dans la bibliothèque : du phagocycle chez Jasper Fforde". Itinéraires et Contacts de cultures 41 (April 2008): 265-279.

Saint-Gelais, Richard. Fictions Transfuges: la transfictionnalité et ses enjeux. Paris : Éditions du Seuil, "Poétique", 2011.

TV Tropes. "Series/ Hill Street Blues", https://tvtropes.org/pmwiki/pmwiki.php/Series/ HillstreetBlues, last accessed 17 March 2020.

Tymens, Ben, et al. "The exhaustive guide to The Well of Lost Plots", last modified 27 April 2004. http://www.jasperfforde.com/reader/readerwolpguide.html, last accessed 17 March 2020.

Tymens, Ben, et al. "The exhaustive guide to Something Rotten or Something Rotten-decomposed", last modified January 5, 2005, http://www.jasperfforde.com/reader/tn4guide.html, last accessed 17 March 2020.

Waugh, Patricia. Metafiction: The Theory and Practice of Self-Conscious Fiction. London/New York: Routledge, 1984.

White, Susanna. Jane Eyre. DVD. London: BBC WorldWide, 2007.

\section{NOTES}

1. [Alternate history] "depict[s] a fictional world which does not come from either future or past in the strictest sense, but rather from a history which would have taken a different path from the one it has, in reality, taken. To this end, alternate history has to follow a bifurcation from official history, from a determining tipping point: the end of a military conflict, the success or failure of the attempted assassination of a political leader, etc." (Saint-Gelais 1999, 43-44, my translation).

2. According to Genette, quotes are a common intertextual practice but are signalled "with quotation marks, with or without specific references" (Genette 1997, 2). Here, however, the quotes function as allusions: "that is, an enunciation whose full meaning presupposes the perception of a relationship beween it and another text, to which it necessarily refers by some inflections that would otherwise remain illegible" (Genette 1997, 2).

3. No less than nine times, one occurrence being a clear reference to Gilbert and Gubar's essay: "the madwoman in the attic".

4. According to Saint-Gelais, "[...] when one of the following three phenomena occurs, it results in a version [of the original]: when a narrative 'revisits' a story that has already been told from a new perspective [...]; when it subjects this story to an interpretation that diverges more or less 
from the initial plot; finally, and more radically, when a narrative clearly alters the direction of the story from how it has been up until that point" (Saint-Gelais 2011, 139-140, my translation).

5. "Like prequels [...], interpolations should by the end link back up to the original point in the narrative that indicates their temporal limit. Interpolation and prequel of course differ in the sense that the former is constrained by its beginning and end, which does not provide it with much leverage" (Saint-Gelais 2011, 84-85, my translation).

6. "Extending a story questions the limits the original work had set itself. Such a gesture cannot be innocent in a culture that bases its conception of the work as a complete, autonomous entity on the idea of conclusion [...]" (Saint-Gelais 2011, 71, my translation).

7. "The parodic text is granted a special licence to transgress the limits of convention, but, as in the carnival, it can do so only temporarily and only within the controlled confines authorized by the text parodied [...]" (Hutcheon 75).

8. "In the middle of the hospital room was a brightly painted sports car. I blinked twice but it didn't vanish. There was no earthly reason why it should be in the room or even any evidence as to how it got there, the door being only wide enough for a bed, but there it was. [...] The driver was a woman in her mid-thirties who looked sort of familiar.

'Thursday-!' cried the driver with a sense of urgency in her voice.

I frowned. It all looked real and I was definitely sure I had seen the driver somewhere before. [...]

'He didn't die! [...] Men like Acheron don't die that easily! Take the LiteraTec job in Swindon!' [...] I opened my mouth to speak but there was another screech of rubber and the car departed, folding up rather than fading out [...]. I held my head in my hands. The driver had been very familiar. It had been me". (Fforde 2001, 59-60)

9. "In the only occupied bed there was a drowsy and confused woman with her arm in a sling. I knew what I had to say.

'Thursday-!' I shouted excitedly.

The woman in the bed frowned. She looked across at Bowden, who waved back cheerily.

'He didn't die!' I continued, saying now what I knew to be the truth. I could hear the tempest starting to howl again. It wouldn't be long before we were taken away.

'The car crash was a blind! Men like Acheron don't die that easily! Take the LiteraTec job in Swindon!'

The woman in the bed just had time to repeat my last word before the ceiling and floor opened up and we plummeted back into the maelstrom" (Fforde 2001, 278-279)

10. For example, the first chapter is entitled "Monday: Swindon" (Fforde 2012, 1) and so on.

11. See chapter 26 of Lost in a Good Book ("Assignment one: bloophole in Great Expectations", 277-291).

12. See chapter 16 of Lost in a Good Book ("Interview with the Cat", 163-170).

13. "Within the same volume are such elements as the title or the preface and sometimes elements inserted into the interstices of the text, such as chapter titles or certain notes. I will give the name peritext to this first spatial category [...]" (Genette 1997, 10).

14. Jane and Rochester do not pretend to love each other for the sake of the plot, their feelings are quite clear when she is abducted: "Hobbes took Jane by the arm and dragged her back towards the corridor.

'Edward! My Edward!' implored Jane, her arms outstretched to Rochester. 'I won't leave you, my love!'

'Wait a minute,' said Hobbes, still backing away, 'you guys haven't fallen in love yet!'

'In that you would be mistaken,' murmured Rochester [...]". (Fforde 2001, 295)

15. Fforde begins using this expression for original characters appearing in The Well of Lost Plots. It serves to explain parts of their behaviour, but I believe it can be applied as early as The Eyre Affair, even if he does not formulate this limitation of their personality and range of action quite as well. 
16. "[T]he neo-Victorian character denies the death verdict of the closed book, or any compulsory order of textual residence, through a process of migration that is an extension of fictitious life" (Letissier).

17. Though Dickens's stories were initially part of nineteenth-century popular culture-as they were published as instalments in newspapers-they later moved to classical culture alongside Brontë's, Eliot's or Gaskell's for instance.

18. Millon de Floss, Thursday's official stalker and biographer, whose name has not been translated for the French edition, is a good example.

\section{ABSTRACTS}

Victorian novels form one of the fundamental pillars of Jasper Fforde's Thursday Next cycle. In a parallel world where people are so obsessed with literature that Jane Eyre is abducted from the eponymous manuscript, a literary detective must be sent inside fiction to rescue her. This article will highlight the depth to which Victorian literature permeates this cycle and how Fforde handles the weight of both Victorian novels and their illustrious authors. Fforde parodies Brontë's novel extensively by modifying the hypotext-Jane Eyre doesn't end as the reader thinks it does-and showing how much his characters influence the canonical plot. In so doing, he gains authorship, but the latter is jeopardised as he is only a literary cuckoo, prisoner of Brontë's shadow. He therefore diversifies his approach towards the Victorian canon by expanding a metafictional secondary world so that it seems to become autonomous. This Great Library, which contains all the books that have been and will ever be written, consequently acts like a black hole, and draws all sorts of Victorian characters into the Ffordian universe. Their presence thus enables the author to create an intellectual complicity with the reader, who delights in seeking the references disseminated in the text, and who is inspired to contribute to the Ffordian universe and expand it in fanfictions.

Les romans du canon victorien font partie intégrante du cycle de fantasy uchronique Thursday Next de Jasper Fforde, publié entre 2001 et 2012. L'Affaire Jane Eyre, premier volet de l'ensemble, met en scène un monde parallèle au nôtre dans lequel la population ne vit que pour la littérature. C'est pourquoi, lorsque Jane Eyre est enlevée dans le manuscrit éponyme, une détective littéraire part à sa rescousse au sein du roman de Charlotte Brontë. Il s'agira donc de questionner le degré de porosité qui existe entre le cycle Thursday Next et le canon victorien et d'analyser la manière dont Fforde tente de se défaire du poids des romans victoriens et de leurs illustres auteurs. Fforde parodie le roman de Charlotte Brontë : il modifie l'hypotexte (Jane Eyre se termine par le départ de l'héroïne pour l'Inde avec son cousin) et les actions de ses personnages ont un impact essentiel sur la diégèse canonique. Ce faisant, il gagne une certaine auctorité mais cette dernière est mise en péril dans la mesure où il n'est qu'un « coucou littéraire », prisonnier de l'ombre de Brontë. Il choisit donc dans les volets suivants de diversifier son approche du canon victorien. Il développe un monde secondaire profondément métafictionnel qui semble autonome. Cette Grande Bibliothèque, qui contient tous les livres qui ont été et qui seront écrits, fonctionne comme un trou noir, dont la force centripète attire une multitude de personnages victoriens dans l'univers ffordien. Leur présence permet l'établissement d'une connivence intellectuelle entre l'auteur et ses lecteurs. Ces derniers partent en quête des références disséminées dans le texte et participent à l'expansion de l'univers ffordien dans des fanfictions. 
INDEX

oeuvrecitee Alice's Adventures in Wonderland, Great Expectations, Eyre Affair (The), Jane Eyre, Lost in a Good Book, Thursday Next series, Well of Lost Plots (The), Wide Sargasso Sea, Woman who died a lot (The), Wuthering Heights

Keywords: fantasy, Victorian canon, authorship, transfiction, metafiction, reader

Mots-clés: fantasy, canon victorien, auctorité, transfiction, métafiction, lecteur

\section{AUTHORS}

\section{AMELHA TIMONER}

Amelha Timoner is a PhD candidate at the Université Paris Nanterre. After studying crises of authority in Philip Pullman's His Dark Materials for her MA dissertation, she is now preparing a doctoral thesis on the same topic but focusing on a different author, Jasper Fforde. Her main research interests include fantasy fiction, transfictionality, children's literature and canon/fanon relationships. 